\title{
The Toxic Effects of Paraquat (PQ) on Body Weights and Haematological Parameters in Male Albino Wistar Rats and its Amelioration with Vitamin C
}

\author{
Kothinti Busa Ashok Kumar Reddy ${ }^{1 *}$, M. Jeevanalatha ${ }^{2}$, \\ M. Lakshman ${ }^{1}$ and M. Usha Rani ${ }^{3}$ \\ ${ }^{1}$ Department of Veterinary Pathology, College of Veterinary Science, \\ Rajendranagar, Hyderabad-500030, India \\ ${ }^{2}$ Department of Veterinary Pathology, College of Veterinary Science, Mamnoor, \\ Warangal-506166, India \\ ${ }^{3}$ Department of Veterinary Pharmacology and Toxicology, College of Veterinary Science, \\ Rajendranagar, Hyderabad-500030, India \\ *Corresponding author
}

\section{A B S T R A C T}

\section{Keywords}

Paraquat, Vitamin C, Body weights, Haematology, Multiple organ failure, Albino wistar rats

Article Info

Accepted:

04 October 2019

Available Online:

10 November 2019
The present experiment was carried out to investigate the protective effect of Vitamin $\mathrm{C}$ on body weights and haematological parameters following paraquat (PQ) intoxication in rats. Total of 48 male albino Wistar rats were procured and divided into 4 groups consisting of 12 in each. Group 1- Control. Group 2 - Paraquat (PQ) at the rate of 40 milligram $/ \mathrm{kg}$ body weight/per oral/day. Group 3 - Vitamin $\mathrm{C}$ at the rate of 250 milligram $/ \mathrm{kg}$ body weight/per oral/day. Group 4 - paraquat (PQ) at the rate of 40 milligram $/ \mathrm{kg}$ body weight/per oral/day + Vitamin $\mathrm{C}$ at the rate of $250 \mathrm{milligram} / \mathrm{kg}$ body weight/per oral $/$ day. The experiment was carried out for a period of 21 days. Group 4 rats revealed a significant $(\mathrm{P}<0.05)$ increase in the mean values of body weights, erythrocyte indices, total erythrocyte count (TEC), total leucocyte count (TLC) and $\mathrm{Hb}$ concentration except packed cell volume (PCV) which was insignificant when compared with group 2 rats. These results suggested that the Vitamin C administration offered remarkable protection against PQ induced alterations in body weights and haematology.

\section{Introduction}

Herbicides or weed killers, are phytotoxic chemicals used for destroying various weeds or inhibiting their growth (Gupta, 2018).
These herbicides are being rapidly used in developing countries due to shortage of hand weeding labour and to enhance the crop production (Hossain, 2015). The paraquat (PQ) is one among them which has been used 
Worldwide for its high efficiency, low pollution and low residues in crops (Ren et al., 2014).

The PQ (1, 1'- dimethyl- 4,4'- bipyridlium dichloride) is a non-selective nitrogen herbicide for broadleaf weed control (Guoet al., 2015). Globally, it is the second highest selling herbicide with availability at the rate of 20 percent solution form (Bandayet al., 2013). It is highly toxic to both humans and animals (Suntres, 2002) potentially leading to Acute Respiratory Distress Syndrome (ARDS) (Huang et al., 2005). The mechanisms of PQ are not fully understood, but it was assumed that the toxicity was due to generation of reactive oxygen species (ROS) through redoxcycling process, resulting in oxidative stressrelated damage to cellular organelles, proteins, nucleic acids and lipids (Adam et al., 1990; Bonneh-Barkey et al., 2005 and Castello et al., 2007). Severe PQ toxicity is characterized by multiple organ failure predominantly lungs, kidneys and liver (Tavakol et al., 2015).

The cause of death is respiratory failure resulting from progressive pulmonary fibrosis, because PQ tends to accumulate in clara cells, type I and II pneumocytes through polyamine uptake system (Dinis-oliveira et al., 2009).

The Vitamin C (Ascorbic Acid-AA) is a water soluble vitamin which can directly scavenge the ROS with and without enzyme catalyst, and can indirectly scavenge them by recycling $\mathrm{NADP}^{+}$to NADPH (Okolonkwo et al., 2014). The fatality rates of PQ toxicity are very high due to lack of effective treatments ( $\mathrm{Hu}$ et al., 2017).

Hence, there is a need to study the effective antidotes against PQ induced toxicity. The aim of this experiment was to investigate the protective effect of Vitamin $\mathrm{C}$ on body weights and hematological parameters after repeated exposure of PQ in Wistar rats.

\section{Materials and Methods}

In the present study, a total of 48 male albino Wistar rats weighing 200-250 grams were procured from Sanzyme Laboratories Ltd, Hyderabad. The rats were housed in solid bottom polypropylene cages at Ruska Labs, Hyderabad and were maintained in controlled environment $\left(20-22^{0} \mathrm{C}\right)$ throughout the course of experiment. Sterile husk was used as standard bedding material. All the rats were provided with standard pellet diet procured from Vyas Labs, Uppal, Hyderabad and deionized water at ad libitum throughout the experimental period.

Rats were randomly divided into 4 groups consisting of 12 in each group. Group 1 served as control whereas group 2 served as PQ toxic control (@ 40 mg/kg b.wt/per oral/day). Group 3 and group 4 rats were administered with Vitamin C (@ $250 \mathrm{mg} / \mathrm{kg} \mathrm{b.wt} /$ day) and PQ (@40 mg/kg b.wt/day) + Vitamin C (@ $250 \mathrm{mg} / \mathrm{kg} \mathrm{b.wt/day)} \mathrm{respectively.}$

The experiment was carried out according to the guidelines and prior approval of Institutional Animals Ethics Committee (IAEC-No.02-2019).

\section{Drugs and chemicals}

Paraquat (Gramoxone ${ }^{\circledR}-24 \%$ w/v solution) was procured from Seed Research and Technology Center, Professor Jayashankar Telangana State Agriculture University, Rajendranagar, Hyderabad which was manufactured by Syngenta India Ltd. Delhi. Ascorbic acid (Vitamin C) as L-Ascorbic acid was obtained from S.D. Fine-Chem Ltd., Mumbai, India.

\section{Growth rate}

Individual body weights of all the rats were recorded by using electronic balance on day 
zero and subsequently on $7^{\text {th }}, 14^{\text {th }}$ and $21^{\text {st }}$ day of experiment to study body weight gains.

\section{Haematology}

Prior to blood collection, the selected experimental rats were put to fast for 12 hours. On the day of sacrifice, six (6) rats from each group were used for blood collection (approximately 2-3mL) through retro-orbital plexus with the help of capillary tube into an anticoagulant coated vacutainer $\left\{\left(\mathrm{K}_{3}\right.\right.$-EDTA tube, $13 \mathrm{~mm}$ x $75 \mathrm{~mm}, \quad 4 \mathrm{~mL}$ (Rapid Diagnostics Pvt. Ltd., Delhi) \} to carry out all haematological parameters. The whole blood was used for estimation of Total Erythrocyte Count (TEC), Total Leukocyte Count (TLC), Haemoglobin $(\mathrm{Hb})$ concentration, Packed Cell Volume (PCV) and erythrocyte indices \{Mean Corpuscular Volume (MCV), Mean Corpuscular Haemoglobin (MCH) and Mean Corpuscular Haemoglobin Concentration (MCHC) \} by using automatic whole blood analyser (Huma count, med source ozone biomedical Pvt. Ltd., Faridabad, Haryana).

Data obtained (body weights and haematological) was subjected to statistical analysis by applying one-way ANOVA and using statistical package for social sciences (SPSS) version 25.0. Differences between the means were tested by using Duncan's multiple comparison tests and significance level was set at $\mathrm{P}<0.05$ (Snedecor and Cochran, 1994).

\section{Results and Discussion}

\section{Weekly body weight gain (g)}

Significantly $(\mathrm{P}<0.05)$ lower mean values of weekly body weights were recorded in group 2 rats $(255.00 \pm 4.49, \quad 253.00 \pm 2.28$ and $243.67 \pm 2.01)$ when compared to group $1(285.50 \pm 3.60, \quad 318.17 \pm 5.02 \quad$ and $347.00 \pm 3.46), \quad$ group $3 \quad(272.00 \pm 3.49$, $317.33 \pm 4.48$ and $333.83 \pm 2.60$ ) and group 4 rats $(267.00 \pm 2.73, \quad 282.83 \pm 2.39 \quad$ and $287.83 \pm 5.59)$ on $7^{\text {th }}, 14^{\text {th }}$ and $21^{\text {st }}$ day of experiment (Table 1).

\section{Haematology}

The mean values of TEC (millions $/ \mu \mathrm{L}$ ) in different groups $(1,2,3$ and 4) were ranged from $8.13 \pm 0.18$ to $9.88 \pm 0.10$ on $7^{\text {th }}$ dayand $7.80 \pm 0.33$ to $9.77 \pm 0.12$ on $21^{\text {st }}$ day of experiment. Significantly $(\mathrm{P}<0.05)$ decreased values were observed in group 2 rats when compared to groups $(1,3$ and 4$)$ on $7^{\text {th }}$ and $21^{\text {st }}$ day of experiment (Table 2).

The mean values of TLC (thousands/ $\mu \mathrm{L}$ ) in different groups $(1,2,3$ and 4) were ranged from $9.17 \pm 0.29$ to $13.04 \pm 0.42$ on $7^{\text {th }}$ day and $8.34 \pm 0.21$ to $13.78 \pm 0.37$ on $21^{\text {st }}$ day of experiment. Group 2 rats showed a significant $(\mathrm{P}<0.05)$ decrease in the TLC values when compared with group 1 , group 2 and group 3 rats on $7^{\text {th }}$ and $21^{\text {st }}$ day of the experiment (Table 2).

The $\mathrm{Hb}$ concentration $(\mathrm{g} \%)$ mean values were significantly $(\mathrm{P}<0.05)$ reduced in group 2 rats $(13.60 \pm 0.23$ and $12.09 \pm 0.16)$ when compared with group $1(16.60 \pm 0.18$ and $16.22 \pm 0.36)$, group $3 \quad(17.06 \pm 0.45$ and $17.10 \pm 0.52)$ and group $4(15.85 \pm 0.15$ and

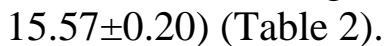

The PCV (\%) mean values were insignificantly varied in between the groups on $7^{\text {th }}$ and $21^{\text {st }}$ day of experiment, but there was a numerical elevation in the mean values of group 2 rats when compared with groups 1 and 3 rats on $7^{\text {th }}$ and $21^{\text {st }}$ day of experiment (Table 3).

The MCV mean values were significantly $(\mathrm{P}<0.05)$ reduced in group 2 animals (48.76 \pm 0.78 and $49.53 \pm 0.45)$ when compared with groups $1(53.24 \pm 0.25$ and $52.74 \pm 0.68)$, group $3(52.95 \pm 0.52$ and $52.38 \pm 0.71)$ and 
groups $4(51.52 \pm 0.45$ and $51.33 \pm 0.67)$ on $7^{\text {th }}$ and $21^{\text {st }}$ day of experiment (Table 4 ).

The mean values of $\mathrm{MCH}$ in different groups $(1,2,3$ and 4$)$ were ranged from $14.72 \pm 0.52$ to $16.83 \pm 0.27$ on day $7^{\text {th }}$ and $15.71 \pm 0.68$ to $17.29 \pm 0.46$ on day $21^{\text {st }}$ of experiment. Significantly $(\mathrm{P}<0.05)$ lowered mean values were recorded in group 2 rats when compared to group 1, group 3 and group 4 rats on $7^{\text {th }}$ and $21^{\text {st }}$ day of experiment (Table 4).

The mean values of MCHC were significantly $(\mathrm{P}<0.05)$ decreased in group 2 rats (30.86 \pm 0.19 and $31.31 \pm 0.21$ ) when compared to group $1(34.22 \pm 0.21$ and $33.85 \pm 0.15)$, group $3(33.62 \pm 0.10$ and $33.79 \pm 0.36)$ and group 4 rats $(32.70 \pm 0.32$ and $33.42 \pm 0.41)$ on $7^{\text {th }}$ and $21^{\text {st }}$ day of experiment (Table 4 ).

The weight loss could be due to reduced feed and water intake, on the account of toxic action of PQ on GIT and also might be due to free radical induced oxidative damage at sub cellular level in different vital organs. This observation is in accordance with the earlier studies of Dinis-Olievera et al., (2008); Lalruatfela et al., (2014); Haripriya et al., (2017); $\mathrm{Hu}$ et al., (2017) and Pourgholamhossein et al., (2018).

These alterations in the mean values of TEC and $\mathrm{Hb}$ concentration could be due to haemolysis by the free radical mediated damage to erythrocyte membrane and similar opinion was expressed by Sato et al., (1995). The findings in the present study are in harmony with the authors (Vuksa et al., 1983 and Lalruatfela et al., 2014) previous studies. In the present study, the changes in TLC mean values were similar to the observations of Nagao et al., (1994) who had explained lower TLC values were due to the toxic effect of PQ on leucopoiesis. An insignificant elevated mean values of PCV might be due to haemoconcentration results from fluid loss due to mild diarrhoea and these findings are in accordance with the earlier studies of Wershana (2001).The reduction in mean values of erythrocyte indices $(\mathrm{MCV}, \mathrm{MCH}$ and $\mathrm{MCHC}$ ) in the present study might be due to toxic effect of PQ on haemopoietic system and the findings are in accordance with the earlier studies of Lalruatfela et al., (2014)

In group 4, a significant increase in the mean values of weekly body weights, TEC, TLC, $\mathrm{Hb}$ concentration and erythrocyte indices except PCV were observed when compared to group 2 which might be due to Vitamin $\mathrm{C}$ antioxidant defence action against PQ induced free radical mediated oxidative stress in different tissues including blood cells.

In conclusion, the present study clearly demonstrated that the administration of Vitamin $\mathrm{C}$ can effectively attenuate PQ induced alterations of body weights and haematology, possibly via antioxidant defence mechanism.

Table.1 Weekly body weight gain (grams) in different groups

\begin{tabular}{|c|c|c|c|}
\hline GROUP & DAY 7 & DAY 14 & DAY 21 \\
\hline G 1 (CONTROL) & $285.50 \pm 3.60^{\mathrm{a}}$ & $318.17 \pm 5.02^{\mathrm{a}}$ & $347.00 \pm 3.46^{\mathrm{a}}$ \\
\hline G 2 (PQ) & $255.00 \pm 4.49^{\mathrm{c}}$ & $253.00 \pm 2.28^{\mathrm{c}}$ & $243.67 \pm 2.01^{\mathrm{d}}$ \\
\hline G 3 (VITAMIN C) & $272.00 \pm 3.49^{\mathrm{b}}$ & $317.33 \pm 4.48^{\mathrm{a}}$ & $333.83 \pm 2.60^{\mathrm{b}}$ \\
\hline G 4 (PQ+VITAMIN C) & $267.00 \pm 2.73^{\mathrm{b}}$ & $282.83 \pm 2.39^{\mathrm{b}}$ & $287.83 \pm 5.59^{\mathrm{c}}$ \\
\hline
\end{tabular}

Values are Mean \pm SE $(n=6)$; One-way ANOVA

Means with different superscripts in a column differ significantly at $\mathrm{P}<0.05(*)$. 
Table.2 Haematological parameters (TEC, TLC and Hb concentration) in different groups

\begin{tabular}{|c|c|c|c|c|c|c|}
\hline \multirow{2}{*}{ GROUP } & \multicolumn{2}{|c|}{ TEC(Millions/ $\boldsymbol{\mu L}$ ) } & \multicolumn{2}{c|}{ TLC(Thousands/ $\boldsymbol{\mu L})$} & \multicolumn{2}{c|}{ Hb $(\mathbf{g} \%)$} \\
\cline { 2 - 8 } & DAY 7 & DAY 21 & DAY 7 $^{\mathrm{a}}$ & DAY 21 & DAY 7 & DAY 21 \\
\hline G1 & $9.65 \pm 0.15^{\mathrm{a}}$ & $9.55 \pm 0.26^{\mathrm{a}}$ & $13.04 \pm 0.42^{\mathrm{a}}$ & $13.78 \pm 0.37^{\mathrm{a}}$ & $16.60 \pm 0.18^{\mathrm{ab}}$ & $16.22 \pm 0.36^{\mathrm{ab}}$ \\
\hline G 2 & $8.13 \pm 0.18^{\mathrm{c}}$ & $7.80 \pm 0.33^{\mathrm{b}}$ & $9.17 \pm 0.29^{\mathrm{c}}$ & $8.34 \pm 0.21^{\mathrm{c}}$ & $13.60 \pm 0.23^{\mathrm{c}}$ & $12.09 \pm 0.16^{\mathrm{c}}$ \\
\hline G 3 & $9.88 \pm 0.10^{\mathrm{a}}$ & $9.77 \pm 0.12^{\mathrm{a}}$ & $12.76 \pm 0.18^{\mathrm{a}}$ & $13.24 \pm 0.40^{\mathrm{a}}$ & $17.06 \pm 0.45^{\mathrm{a}}$ & $17.10 \pm 0.52^{\mathrm{a}}$ \\
\hline G 4 & $9.23 \pm 0.10^{\mathrm{b}}$ & $9.25 \pm 0.15^{\mathrm{a}}$ & $10.73 \pm 0.17^{\mathrm{b}}$ & $10.15 \pm 0.27^{\mathrm{b}}$ & $15.85 \pm 0.15^{\mathrm{b}}$ & $15.57 \pm 0.20^{\mathrm{b}}$ \\
\hline
\end{tabular}

Values are Mean $\pm \mathrm{SE}(\mathrm{n}=6)$; One-way ANOVA

Means with different superscripts in a column differ significantly at $\mathrm{P}<0.05(*)$.

Table.3 Packed cell volume (\%) in different groups

\begin{tabular}{|c|c|c|}
\hline GROUP & DAY 7 & DAY 21 \\
\hline G 1 & $52.33 \pm 0.20$ & $48.23 \pm 1.57$ \\
\hline G 2 & $55.85 \pm 2.62$ & $49.92 \pm 3.71$ \\
\hline G 3 & $53.43 \pm 1.25$ & $48.27 \pm 2.53$ \\
\hline G 4 & $52.68 \pm 1.60$ & $55.93 \pm 1.96$ \\
\hline
\end{tabular}

Values are Mean \pm SE ( $n=6)$; One-way ANOVA

Means with different superscripts in a column differ significantly at $\mathrm{P}<0.05(*)$.

Table.4 Erythrocyte indices (MCV, $\mathrm{MCH}$ and $\mathrm{MCHC}$ ) in different groups

\begin{tabular}{|c|c|c|c|c|c|c|}
\hline \multirow{2}{*}{ GROUP } & \multicolumn{2}{|c|}{ MCV \{Femtoliter (fL) $\}$} & \multicolumn{2}{c|}{ MCH \{Picogram(pg)\} } & \multicolumn{2}{c|}{$\begin{array}{c}\text { MCHC }\{\text { Grams } \\
\text { perdecilitre (g/dL) }\end{array}$} \\
\cline { 2 - 7 } & DAY 7 & DAY 21 & DAY 7 & DAY 21 & DAY 7 & DAY 21 \\
\hline G1 & $53.24 \pm 0.25^{\mathrm{a}}$ & $52.74 \pm 0.68^{\mathrm{a}}$ & $16.68 \pm 0.30^{\mathrm{a}}$ & $17.29 \pm 0.46^{\mathrm{a}}$ & $34.22 \pm 0.21^{\mathrm{a}}$ & $33.85 \pm 0.15^{\mathrm{a}}$ \\
\hline G 2 & $48.76 \pm 0.78^{\mathrm{c}}$ & $49.53 \pm 0.45^{\mathrm{b}}$ & $14.72 \pm 0.52^{\mathrm{b}}$ & $15.71 \pm 0.68^{\mathrm{b}}$ & $30.86 \pm 0.19^{\mathrm{c}}$ & $31.31 \pm 0.21^{\mathrm{b}}$ \\
\hline G 3 & $52.95 \pm 0.52^{\mathrm{ab}}$ & $52.38 \pm 0.71^{\mathrm{a}}$ & $16.83 \pm 0.27^{\mathrm{a}}$ & $17.22 \pm 0.31^{\mathrm{a}}$ & $33.62 \pm 0.10^{\mathrm{a}}$ & $33.79 \pm 0.36^{\mathrm{a}}$ \\
\hline G 4 & $51.52 \pm 0.45^{\mathrm{b}}$ & $51.33 \pm 0.67^{\mathrm{ab}}$ & $15.98 \pm 0.87^{\mathrm{a}}$ & $16.35 \pm 0.93^{\mathrm{ab}}$ & $32.70 \pm 0.32^{\mathrm{b}}$ & $33.42 \pm 0.41^{\mathrm{a}}$ \\
\hline
\end{tabular}

Values are Mean $\pm \mathrm{SE}(\mathrm{n}=6)$; One-way ANOVA

Means with different superscripts in a column differ significantly at $\mathrm{P}<0.05\left(^{*}\right)$.

\section{Aknowledgements}

The authors are thankful to P V Narsimha Rao Telangana Veterinary University for providing support and necessary facilities to carry out the research work.

\section{References}

Adam, A., Smith, L. L. and Cohen, G. M. (1990). An assessment of the role of redox cycling in mediating the toxicity of paraquat and nitrofurantoin. Environmental Health Perspectives. 85: 113-117.

Banday, T. H., Bashir, S., Bhat, S., Aswin, K., Praveen, and Jagadeesh, S.G. (2013). Manifestation and Management of Paraquat Intoxiction. A deadly poison? IOSR Journal of Dental and Medical Sciences (IOSR-JDMS). 12 (6): 74-76.

Bonneh-Barkay, D., Reaney, S. H., Langston, W. J. and Di Monte, D. A. (2005). Redox cycling of the herbicide 
paraquat in microglial cultures. Molecular Brain Research. 134(1): 5256.

Castello, P. R., Drechsel, D. A. and Patel, M. (2007). Mitochondria are a major source of paraquat-induced reactive oxygen species production in the brain. Journal of Biological Chemistry. 282(19): 14186-14193.

Dinis-Oliveira, R. J., Duarte, J. A., SanchezNavarro, A., Remiao, F., Bastos, M. L. and Carvalho, F. (2008). Paraquat poisonings: mechanisms of lungtoxicity, clinical features, and treatment. Critical Reviews in Toxicology. 38 (1):13-71.

Dinis-Oliveira, R. J., de Pinho, P. G., Santos, L., Teixeira, H., Magalhães, T., Santos, A., Bastos, M. L., Remiao, F., Duarte, J. A. and Carvalho, F. (2009). Postmortem analyses unveil the poor efficacy of decontamination, antiinflammatory and immunosuppressive therapies in paraquat human intoxications. PLOS one. 4(9): e7149.

Guo, F., Sun, Y. B., Su, L., Li, S., Liu, Z. F., Li, J., Hu, X. T. and Li, J. (2015). Losartan attenuates paraquat-induced pulmonary fibrosis in rats. Human and Experimental Toxicology.34 (5): 497 505.

Gupta, P.K. (2018). Toxicity of Herbicides. Veterinary Toxicology, Basic and Clinical Principles, $3^{\text {rd }}$ edn., Elsevier: 553-567.

Haripriya, B., Lakshman, M. and Sudha, V. (2017). Influence of paraquat (PQ) induced acute toxicity on body weights and haemato-biochemical parameters in experimental rats. International Journal of Livestock Research.6 (7): 396-398.

Hossain, M. M. (2015). Recent perspective of herbicide: Review of demand and adoption in world agriculture. Journal of the Bangladesh Agricultural
University. 13 (1): 13-24.

Hu, X., Shen, H., Wang, Y. and Zhao, M. (2017). Liver X receptor agonist TO901317 attenuates paraquat-induced acute lung injury through inhibition of NF- $\mathrm{kB}$ and JNK/p38 MAPK signal pathways. BioMed Research International. 2017.

Huang, C. J., Yang, M. C. and Ueng, S. H. (2005). Subacute pulmonary manifestation in a survivor of severe paraquat intoxication. The American Journal of the Medical Sciences. 330(5): 254-256.

Lalruatfela, P. L., Saminathan, M., Ingole, R. S., Dhama, K. and Joshi, M. V. (2014). Toxicopathology of paraquat herbicide in female wistar rats. Asian Journal of Animal and Veterinary Advances. 9 (9): 523-542.

Nagao, M., Zhang, W. D., Takatori, T., Itakura, Y., Yamada, Y., Iwase, H., Oono, T. and Iwadate, K. (1994). Identification and dynamics of paraquat in the bone marrow, thymus and spleen in rats using immunohistochemical techniques. The Japanese Journal of Legal Medicine. 48(3): 166-168.

Okolonkwo, B. N., Nwachuku, E. O., Ene, P. C. and Okeke, C. U. (2014). The preventive effect of vitamin $\mathrm{C}$ on the cellular and functional integrity of kidney cells in rats following repeated exposure to paraquat. Journal of Xenobiotics.4 (1):29-39.

Pourgholamhossein, F., Rasooli, R., Pournamdari, M., Pourgholi, L., Samareh-Fekri, M., Ghazi-Khansari, M., Iranpour, M., Poursalehi, H. R., Heidari, M. R. and Mandegary, A. (2018). Pirfenidone protects against paraquat-induced lung injury and fibrosis in mice by modulation of inflammation, oxidative stress, and gene expression. Food and Chemical 
Toxicology. 112: 39-46.

Ren, M., Wang, Y. M., Zhao, J., Zhao, J., Zhao, Z. M., Zhang, T. F., He, J., Ren, S. P. and Peng, S. Q. (2014). Metallothioneins attenuate paraquatinduced acute lung injury in mice through the mechanisms of antioxidation and anti-apoptosis. Food and Chemical Toxicology. 73: 140-147.

Sato, Y., Kamo, S., Takahashi, T. and Suzuki, Y. (1995). Mechanism of free radicalinduced hemolysis of human erythrocytes: hemolysis by watersoluble radical initiator. Biochemistry. 34(28): 8940-8949.

Snedecor, G. W. and Cochran, W. G.(1994). Statistical methods, $8^{\text {th }}$ Edn., Ames: Iowa State Univ. Press Iowa.

Suntres, Z. E. (2002). Role of antioxidants in paraquat toxicity. Toxicology. 180 (1): 65-77.

Tavakol, H. S., Farzad, K., Fariba, M., Abdolkarim, C., Hassan, G., SeyedMostafa, H. Z. and Akram, R. (2015). Hepatoprotective effect of Matricaria chamomilla. L in paraquat induced rat liver injury. Drug Research. 65 (02): 61-64.

Vuksa, M., Neskovic, N., Vitorovic, S. and Karan, V. (1983). Subacute toxicity of paraquat in rats-biochemical effects. Ecotoxicology and Environmental Safety. 7 (5): 475-483.

Wershana, K. Z. (2001). The influence of vitamin $\mathrm{C}$ or selenium on paraquat induced toxicity in Guinea Pigs. Pakistan Journal Biological Sciences.4: 81-88.

\section{How to cite this article:}

Kothinti Busa Ashok Kumar Reddy, M. Jeevanalatha, M. Lakshman and Usha Rani, M. 2019. The Toxic Effects of Paraquat (PQ) on Body Weights and Haematological Parameters in Male Albino Wistar Rats and its Amelioration with Vitamin C. Int.J.Curr.Microbiol.App.Sci. 8(11): 314-320. doi: https://doi.org/10.20546/ijcmas.2019.811.039 